\author{
Marian Poniewiera \\ ORCID: 0000-0003-0855-7105 \\ Violetta Sokoła Szewioła \\ ORCID: 0000-0001-6147-9594
}

\title{
MODELING OF THE QUALITY OF DEPOSITS IN THE UPPER SILESIAN REGION BASED ON IT SYSTEM
}

\author{
The Faculty of Mining and Geology of Silesian University of Technology
}

Keywords: Numerical Model of the Deposit; mining digital maps; quality of deposit

\begin{abstract}
In every mining company, the process of extracting deposits requires recalculating resources and, consequently, updating surveying-geological documentation. This documentation is necessary, among other things, to introduce changes to the deposit development project, the mining company operation plan, and finally, for proper planning of activities in the field of processing, namely pollution removal of the mining spoil, as well as transport and sale. Software was developed that allows you to create spatial models of deposits. The article presents solutions applied in this scope in the majority of mining enterprises conducting underground hard coal excavation in the Upper Silesian Region. The applied system, called the Numerical Model of the Deposit, uses the Oracle Spatial, AutoCAD Civil 3D, GEONET, GEOLISP, EDBJ-OPN software. The article focuses on the possibilities of the system in the aspect of coal quality assessment based on chemical, physicochemical, physical and petrographic methods. Basic functionalities of the system that uses the qualitative model of the deposit were presented. Chemical analyses of coal made by laboratories are recorded on a current basis into a relational database, and then verified by an authorized geologist. It allows us, among others, to supplement geological data of lots with attributes such as: field, tonnage, average fall, sulphation, etc.
\end{abstract}

\section{MODELOWANIE JAKOŚCI ZLÓ̇̇ W REJONIE GZW Z WYKORZYSTANIEM NARZĘDZI INFORMATYCZNYCH}

Słowa kluczowe: numeryczny model złoża, górnicza mapa numeryczna, jakość złoża

\begin{abstract}
Abstrakt
W każdym zakładzie górniczym w procesie wydobywania złóż występuje konieczność ponownego przeliczenia zasobów, a co za tym idzie aktualizacji dokumentacji mierniczo-geologicznej. Dokumentacja ta jest niezbędna m.in. do wprowadzenia zmian w projekcie zagospodarowania złoża, planie ruchu zakładu górniczego i w końcu do poprawnego zaplanowania działań w zakresie przeróbki (usuwania zanieczyszczeń urobku), transportu i sprzedaży. Opracowano oprogramowanie, które pozwala na tworzenie modeli przestrzennych złóż. Są to modele interaktywne i numeryczne. W artykule przedstawiono rozwiązania w tym zakresie stosowane w większości przedsiębiorstw górniczych prowadzących podziemną eksploatację węgla kamiennego w rejonie GZW. Zastosowany system, o nazwie Numeryczny Model Złoża, wykorzystuje programy Oracle Spatial, AutoCAD Civil 3D, GEONET, GEOLISP, EDBJ. W artykule skupiono się na możliwościach systemu w aspekcie oceny jakości węgla w oparciu o metody chemiczne, fizykochemiczne, fizyczne i petrograficzne. Przedstawiono podstawowe funkcjonalności wykorzystujące jakościowy model złoża. Wykonane przez laboratorium analizy chemiczne węgla zapisywane są na bieżąco do relacyjnej bazy danych. Następnie, po weryfikacji przez uprawnionego geologa, trafiają na mapę numeryczną, co dalej pozwala na uzupełnienie danych parcel geologicznych o atrybuty takie jak: pole, tonaż, średni upad, zasiarczenie itp.
\end{abstract}




\section{INTRODUCTION}

Pursuant to the Geological and Mining Law Act (Regulation, 2015), PGI-NRI (Polish Geological Institute National Research Institute) is responsible for the diagnosis of the deep geological structure of the country. The Institute is also responsible for parametric modeling of shallow geological structures in Poland. The models are developed based on the visualization of the spatial distribution of stratigraphic, lithological strata including hydrogeological parameters. Another branch includes geological models implemented by entrepreneurs, which are mainly numerical models, used for planning exploitation, estimating the amount of resources, supporting the quality and quantity management of a given mineral. The Numerical Model of the Deposit is the most important element in the operation management of individual mines and mining plants. The issue of further development in the scope of modeling by PGI NRI remains extremely important due to the fact that these models should be the starting point for creating more advanced numerical models all over the country. The current available models of geological structures have been developed by the Spatial Modeling Team of the Geological Cartography Department of the Polish Geological Institute. In addition to geological models illustrating the geological structure of a particular area, we also distinguish numerical models that illustrate the structure of the deposit and serve mainly as data management systems based on the input data. The data are basically introduced on an ongoing basis in accordance with the progress of mining operations and are also used to plan the exploitation.

The applicable legal regulations in Poland allow for the creation in the mining enterprises of surveying geological documentation, measuring, computational and cartographic documents, in a numerical form. To this end, enterprises use different combinations of IT and technology environments to develop the Numerical Model of the Deposit (Chen et al., 2004). At KGHM Polish Copper Inc. the software is based on the Oracle database and the MicroStation environment. In addition, attempts to create a numerical model were also made in private companies, scientific units acting on behalf of a mine or other private companies as a part of scientific activities undertaken with the active involvement of a team of geologists in a particular mine. Over the past few years, there have been some solutions based on the software SoftMine used to create models of deposits developed by a private company PRGW Geological and Drilling Works Enterprise in Sosnowiec). The largest project to date in the Polish mining industry was the implementation of the Numerical Model of the Deposit in the Coal Company (currently Polish Mining Group / Inc) (Jelonek et al., 2015).

Despite the many professional numerical service systems available on the Polish market (Biegun, Krawczyk, 2016; Maciaszek et al., 2015), the majority of companies in hard coal mining use the above-mentioned system called the Numerical Model of the Deposit (NMD). The system includes: AutoCAD Civil 3D, Oracle Spatial, EDBJ, GEONET and GEOLISP. The most important element of the system is the GEOLISP software, which allows for preparation of surveyinggeological documentation in a standard compliant with the law and meeting the requirements that allow presentation of objects constituting the content of mining maps in accordance with the requirements of Polish standards - mining maps included in the Geodetic and Cartographic Law Act. The author of the program is also the co-author of the article. Issues related to the numerical model constitute the subject of various projects, including research ones. The results were presented in the works (Sokoła-Szewioła, Poniewiera, 2017; 2019; Poniewiera et al., 2019).

The article focuses on the possibilities of the system in the aspect of coal quality assessment based on chemical, physico-chemical, physical and petrographic methods. Basic functionalities of the system that uses the qualitative model of the deposit were presented. Chemical analyses of coal made by a laboratory are recorded on a current basis into a relational database, and then verified by an authorized geologist. It allows us, among others, to supplement geological data of lots with attributes such as: field, tonnage, average fall, sulphation, etc.

\section{NUMERICAL MODEL OF THE DEPOSIT}

The tool for the construction of NMD is the Oracle Fusion Middleware SOA Suite software. The software implements the construction of internal integration of applications operating within the system with external applications. The applications operating within the system include the following programs: AutoCAD Civil $3 \mathrm{D}$ the software is a graphical environment of the sys- 
tem, which allows integration with relational databases and provides topological analyses; Oracle Spatial a relational database software in a spatial format; EDBJ-OPN a package of programs used to present the effects of mining works both in the rock mass and on the surface; GEONET a package of programs that perform tasks in the field of geodetic and cartographic calculations; GEOLISP software operating in the environment of CAD systems, which allows graphic visualization of database objects in a standard consistent with the requirements for creating cartographic documents in mining enterprises as well as implementation of calculations and preparation of documents enabling the implementation of tasks related to mining plant operations, including the subject of the article; Central Numeric Model of the Deposit - application in the Java programming language, used for power management of the Central Database on the deposit. The system also uses the Oracle SOA Suite, ensuring the launch of net- work services within the company as well as external internet portals (Klemens, Poniewiera, 2010). The architecture of the system is shown in Fig. 1.

Incorporation of information on petrographic and quality parameters of coals into the Numerical Model of the Deposit is extremely important due to the possibility of a quick access to the data. In coal petrography, lithotypes, macerals, microlithotypes, carbominery, minerals and rocks are distinguished. Coal is characterized by macroscopic and microscopic features. In order to determine the suitability of coal in technological processes, an analysis of quality parameters is performed. Coal quality assessment is based on chemical, physical, physicochemical and petrographic methods. The obtained indicators can be used for general quality assessment, e.g. assessment of ash content or moisture, or to assess the suitability of coal in technological processes. A detailed issue is discussed in the works (Jelonek et al., 2017). Indicators (parameters) characterizing the

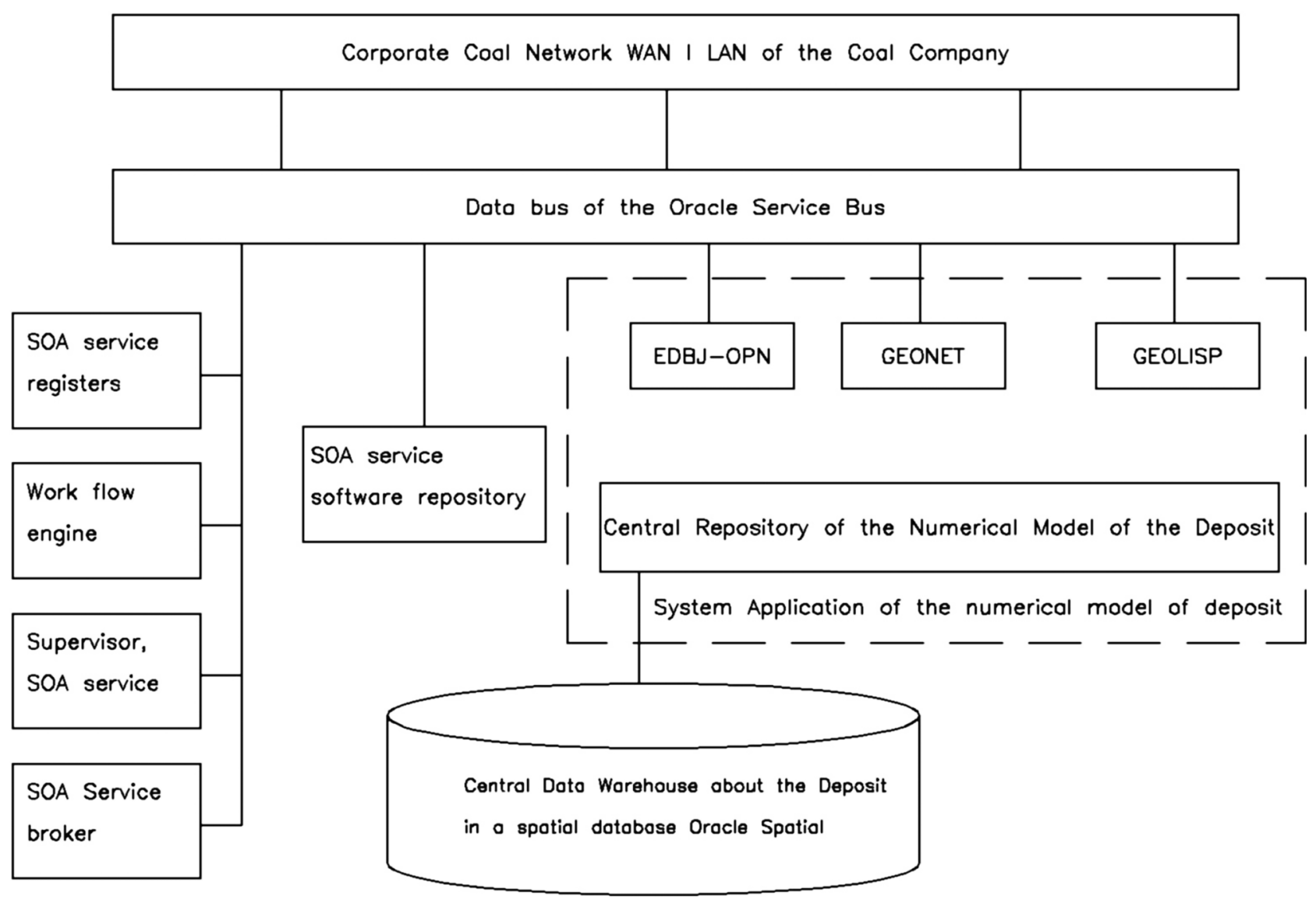

Fig. 1. The architecture of the NMD system

Rys. 1. Architektura systemu NMZ 
quality of coal can be divided into: parameters obtained in the technical analysis process, characterizing the general characteristics of coal, i.e. moisture content, ash content, volatile content, heat of combustion, calorific value; parameters characterizing the elemental composition, obtained as a result of an elemental analysis (content $\mathrm{C}, \mathrm{N}, \mathrm{S}, \mathrm{H}, \mathrm{O}, \mathrm{P}, \mathrm{Cl}$ ); parameters obtained as a result of a technological analysis, e.g. sintering capacity (RI), free release (SI), dilatometric properties, expansion pressure; parameters characterizing a physical analysis, i.e. apparent and real density, mechanical properties, attrition.

\section{METHODOLOGY AND MATERIALS OR EXPERIMENTAL METHODOLOGY AND THEIR CHARACTERISTICS}

The data listed in Chapter 2 are powered by the NMD system, which allows them to be used to model the quality of a deposit. The Geolisp program provides full system functionality in this area (Poniewiera et al., 2015). Basic sources of data for obtaining the above-mentioned indicators are research openings, underground furrow samples or tests carried out during the exploitation of a deposit. The database can be presented in two-dimensional or three-dimensional forms. The system ensures obtaining a cartographic presentation of these data. A digital surface model is created, which is verified on the basis of data contained in raster files. Such an operation can be carried out for all the param-

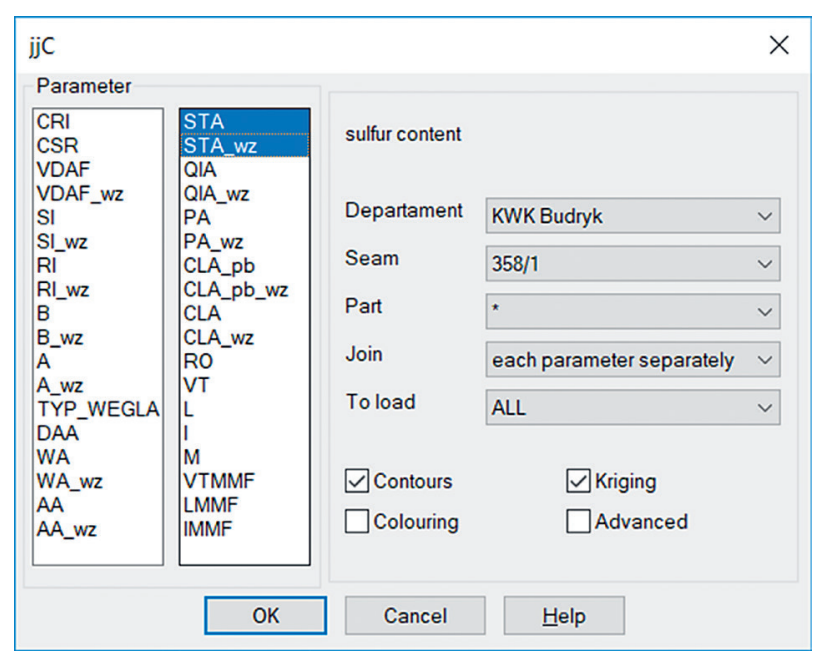

Fig. 2. jjC command dialogue window Rys. 2. Okno dialogowe polecenia jjC eters of the entire mineral deposit we are interested in. The larger the range of selected parameters, the wider the scope of the model.

The following subchapters present the basic functionalities of the system.

\subsection{Creation of deposit quality maps based on a database}

To create quality maps based on Geolisp database, the following commands are available:

- jJSW - the command menu, from which we can call the remaining commands of the quality module.

- $\mathrm{jjC}$ - reads data on the quality from the database, inserts points, blocks, draws isolines and coloring.

- $\mathrm{jj} \mathrm{W}-$ selection of the visible layer.

- jjYes-ignore the indicated sample, the command saves information in the database that a given sample is unreliable or obviously incorrect.

- jjNo - do not ignore the indicated sample, records in the database that the sample is good.

- WB - inserts a block, e.g. CRI (coke reactivity index) - a recommended block for quality.

- wCri - visibility management of the CRI block.

- OpArt - creates a TIN surface based on blocks' attributes.

- OP - TIN surface management, e.g. creates TIN based on points.

- Krig - extrapolation - extension of TIN to the indicated area.

- OpWar - generating and describing isolines.

- OpKol - coloring areas of similar values.

- BlzFile - loading of blocks from a text file.

- Us2blk - we remove double points.

- Cproby - a quality map based on the Excel table.

- Cpkt - loading points from a text file.

- ZNN - finds the next error.

\subsubsection{Loading of data}

The jjC command reads the quality data included in the database (Fig. 2).

It is necessary to enter the data defining the parameter to be read, the mine, the seam and to determine the loading conditions, which will allow for deletion during loading of the wrong samples. 


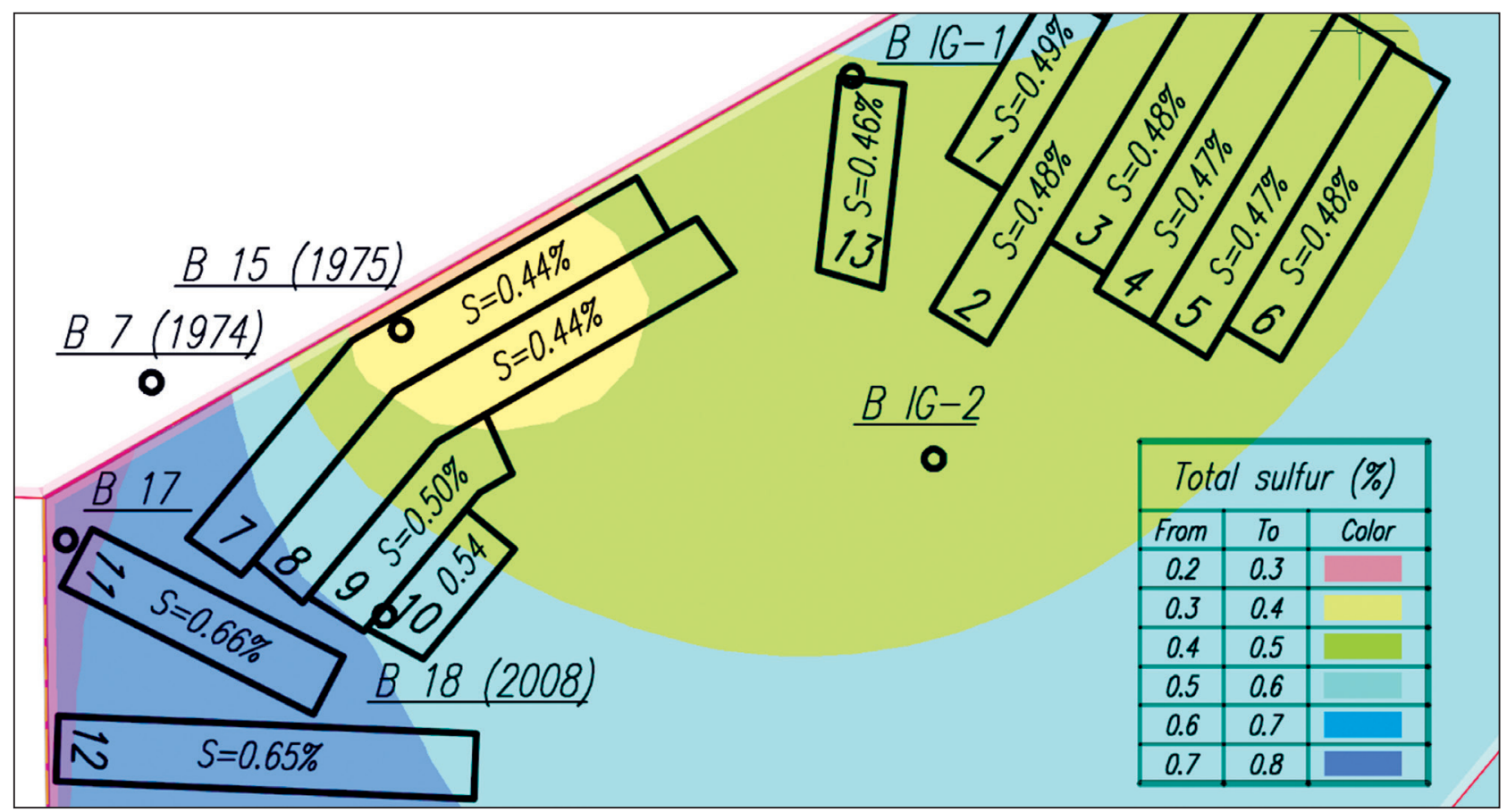

Fig. 3. Generated map of total sulfur (S)

Rys. 3. Wygenerowana mapa własności siarki całkowitej (S)

The program creates a TIN surface and introduces contour lines and coloring to it. Additionally, it is possible to turn on the switch:

- Contour - the contour lines will be selected and described, color, leap and a layer are chosen automatically.

- Coloring - just like the above, coloring will be isolated.

- Kriging - if there is a closed polyline on the "Envelope" layer, the surface will be extended to it.

- Advanced - runs other programs, where it is possible to set the color, leap and other parameters.

Fig. 3 presents the generated map of total sulfur, based on the data obtained from one of the mines in the Upper Silesian Coal Basin (USCB).

\subsubsection{Choice of the visible layer}

In a situation where data is entered into the database, it can be loaded in the scope of the selected parameter (command jjW - Fig. 4). In the "Parameter" file, we choose which parameter we want to display. We choose which layer we want to show in the "Display" file. You can select several values at the same time.

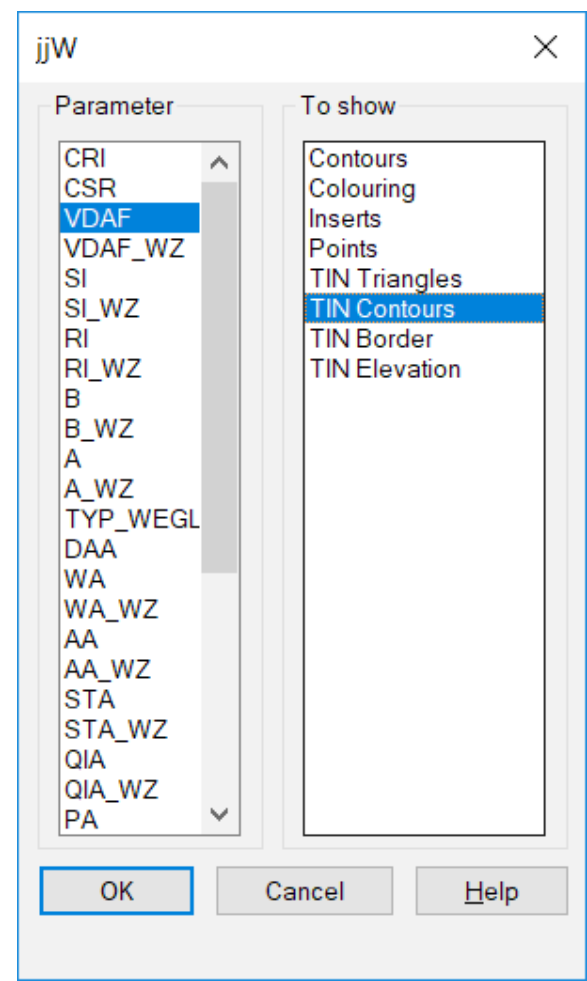

Fig. 4. jjW command dialogue window Rys. 4. Okno dialogowe polecenia jjW 


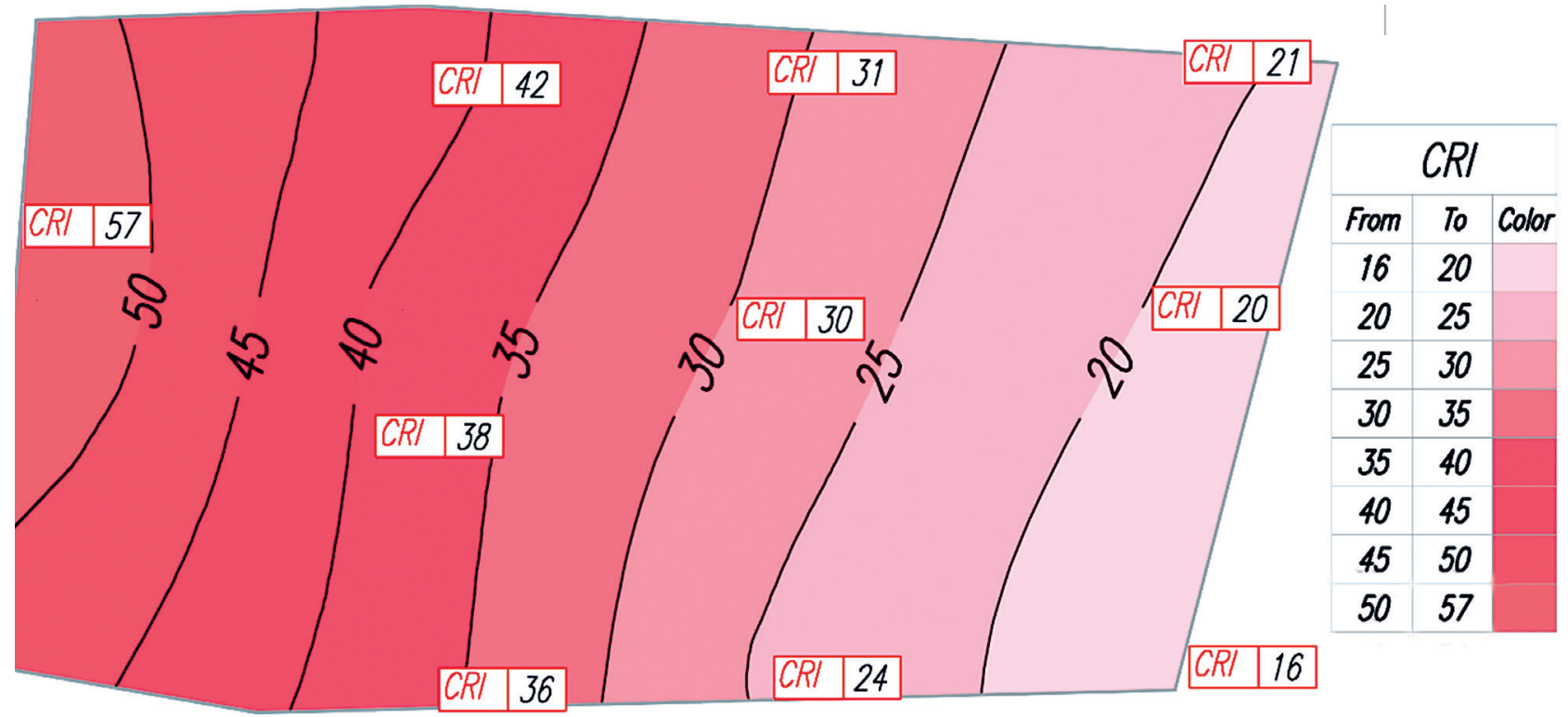

Fig. 5. The map of coke reactivity index generated on the basis of CRI blocks

Rys. 5. Mapa własności koksotwórczych wygenerowana w oparciu o bloki CRI

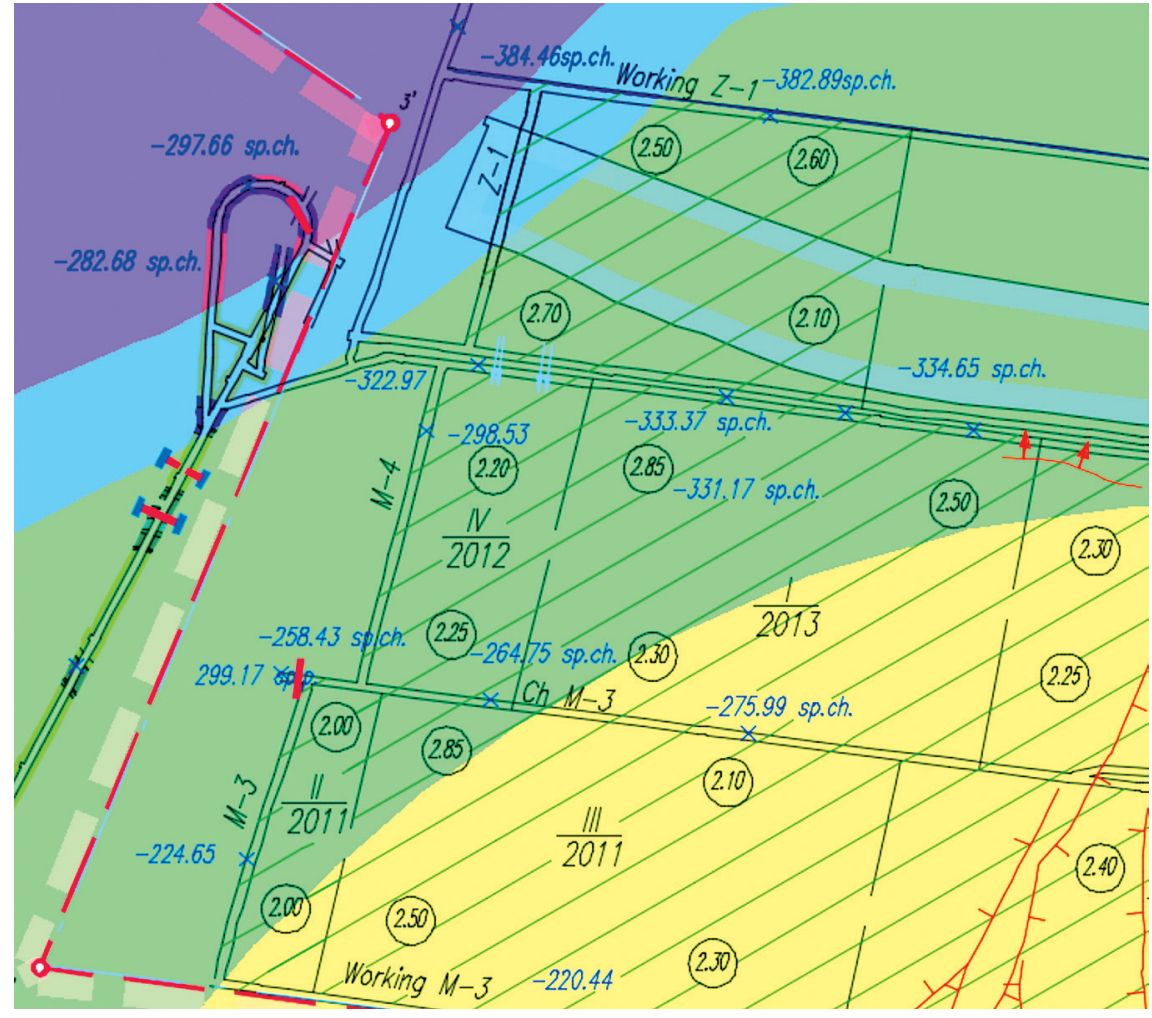

(a)

\begin{tabular}{|c|c|c|}
\hline$X$ & $Y$ & Volatiles \\
\hline 5559656 & 6549564 & 22.9 \\
\hline 5560076 & 6547994 & 27.7 \\
\hline 5559976 & 6548179 & 26.7 \\
\hline 5559880 & 6548419 & 25.9 \\
\hline 5559726 & 6548616 & 24.9 \\
\hline 5559431 & 6548741 & 24.0 \\
\hline 5559409 & 6549055 & 23.2 \\
\hline 5559688 & 6549873 & 23.3 \\
\hline 5560171 & 6550830 & 23.9 \\
\hline 5559899 & 6550882 & 23.5 \\
\hline 5559698 & 6551008 & 23.0 \\
\hline 5559593 & 6551363 & 22.5 \\
\hline 5557287 & 6546825 & 22.3 \\
\hline 5557058 & 6546628 & 22.0 \\
\hline 5556828 & 6546676 & 21.0 \\
\hline 5556230 & 6546709 & 20.5 \\
\hline 5558647 & 6545273 & 28.2 \\
\hline 5558708 & 6545502 & 28.1 \\
\hline 5558664 & 6545749 & 27.9 \\
\hline
\end{tabular}

(b)

Fig. 6. The volatiles map (a) generated based on the data from a text file (b)

Rys. 6. Mapa części lotnych (a) wygenerowana w oparciu o dane z pliku tekstowego (b) 


\subsubsection{Obtaining deposit quality isolines based on CRI blocks}

The system makes it possible to generate isolines of the selected parameter based on CRI blocks (including coal quality parameters - Fig. 5).

The algorithm of the procedure is as follows:

- inserting several CRI blocks,

- introduction of a closed polyline, the envelope of the area in question,

- creation of a TIN surface based on blocks. To create the surface, you can use both blocks and points loaded with the $\mathrm{jjC}$ command,

- activation of the Krig procedure, allowing extrapolation of the grid to the envelope; this command creates a grid of squares with a side of, e.g. $10 \mathrm{~m}$,

- generation and description of contour lines,

- coloring of the areas of similar values (chorochromatic method),

- cartographic presentation, setting the correct display order of objects.

\subsubsection{Creation of a quality map by loading data from a text file}

If you have a text file, you can enter the data from this file. We indicate the seam, the scale of editing, we load the file, remove double points, create a TIN grid for block attributes, e.g. CHEMICAL ANALYSIS, set the selected parameter, for example, ash, we compact the grid for the parameter e.g. every $1 \%$ (Kriging), we set that the grid is to be visualized by coloring (Figures $6 a$ and $6 b)$.

\subsubsection{Development of the parameter range map based on the Excel table}

It is possible to generate the range map of a specific parameter. The program dialogue window is shown in Fig. 7. For this purpose, we choose the seam, the scale and parameter, e.g. "Ash content", then we select what actions the program is to do next: grid density, description of contour lines and coloring of designated areas.

\subsection{Supplementing data for exploitation lots}

The system enables introduction of values of quality parameters for individual exploitation lots. This is done automatically by selecting an appropriate command - in this case tpCT (Fig. 8).

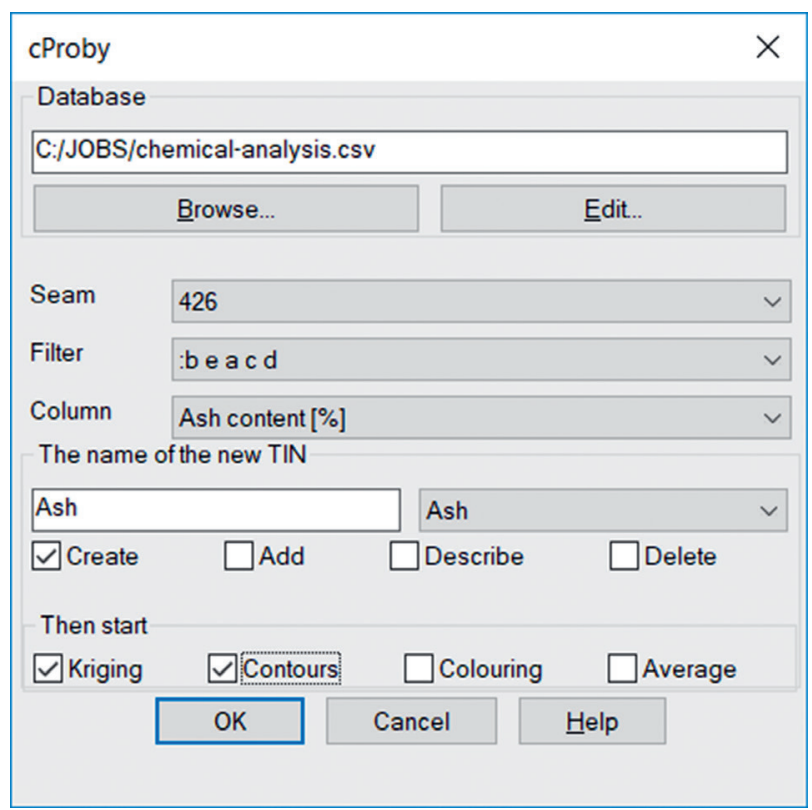

Fig. 7. Parameter loading dialogue window

Rys. 7. Okno dialogowe wczytania parametru

In the presented example, each lot has the following descriptive attributes: thickness volume, field, tonnage, ash, sulfur, density, calorific value, including minimum and maximum values, the total (for attributes: field, volume and tonnage), arithmetic mean and weighted average as well as data on the number of the seam to which the lot is assigned, the lot number, category of recognition of the pillars' deposit, coal type, losses, etc.

This data can be exported to Excel (Fig. 9).

An important element of the system is the ability to use this data by means of the TpData command, with the previously created files: schedule.csv and statement. csv, to create a report.csv file, containing a list of coal qualities in individual months (Fig. 10).

If it is planned to use a longwall system exploitation, each of these walls is shown on the map in the form of closed polylines. Then, with the TpCT command, we calculate the selected quantitative and qualitative parameters for these longwalls, e.g. tonnage or average sulphation value, and export them to Excel with the map2e command. Then, with the tpData command, we create a report where we can see how the tonnage or sulphation changes in individual months and years.

If exploitation of several longwalls is planned in a given month, then you can specify whether the pro- 

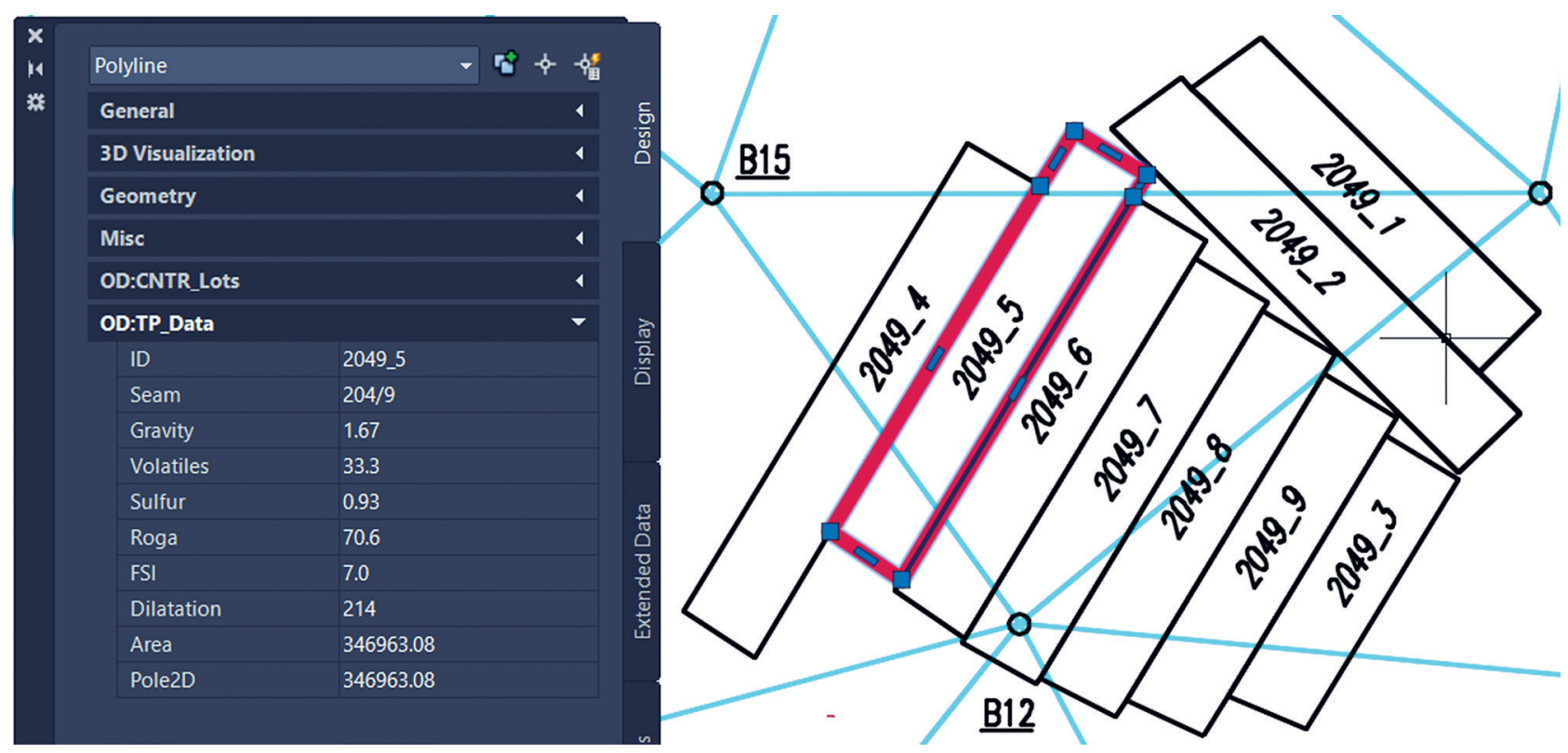

Fig. 8. Attributes of selected exploitation lots

Rys. 8. Atrybuty wybranych parcel eksploatacyjnych

gram should count the average, the minimum or maximum value from these longwalls.

In the reports mentioned above, each longwall is treated as a whole. In the case when coal parameters, e.g. sulphation, are significantly variable in particular months or quarters, we divide the longwall into modules (closed polylines) e.g. quarterly and each module will be treated separately.

\subsection{Modeling of geological lots}

In the GEOLISP program, we can also perform a number of tasks in the scope of creation and analysis of geological lots. At this stage, we can:

- indicate a point inside a closed area - previously delineated boundaries of the lot (usually they are isolines, faults, pillars),

\begin{tabular}{|c|c|c|c|c|c|c|c|c|c|}
\hline 1 & A & B & C & D & $E$ & $\mathrm{~F}$ & G & $\mathrm{H}$ & I \\
\hline 1 & ID & Seam & $\begin{array}{c}\text { Specific } \\
\text { gravity } \\
{\left[\mathrm{G} / \mathrm{cm}^{3}\right]}\end{array}$ & $\begin{array}{c}\text { Volatiles } \\
\text { [\%] }\end{array}$ & $\begin{array}{c}\text { Total } \\
\text { sulfur } \\
{[\%]}\end{array}$ & $\begin{array}{l}\text { Roga } \\
\text { Index }\end{array}$ & $\mathrm{FSI}$ & Dilatation & $\begin{array}{l}\text { Area } \\
{\left[\mathrm{m}^{2}\right]}\end{array}$ \\
\hline 2 & 2049_1 & $204 / 9$ & 1.49 & 33.2 & 1.01 & 74.8 & 7.6 & 114 & 292591 \\
\hline 3 & 2049_2 & $204 / 9$ & 1.53 & 33.4 & 1.01 & 74.0 & 7.5 & 143 & 355749 \\
\hline 4 & 2049_3 & $204 / 9$ & 1.64 & 34.2 & 1.15 & 73.4 & 7.3 & 171 & 220144 \\
\hline 5 & 2049_4 & $204 / 9$ & 1.73 & 33.3 & 0.91 & 71.7 & 7.1 & 198 & 403663 \\
\hline 6 & 2049_5 & $204 / 9$ & 1.67 & 33.3 & 0.93 & 70.6 & 7.0 & 214 & 346963 \\
\hline 7 & 2049 6 & $204 / 9$ & 1.68 & 33.5 & 0.98 & 69.4 & 6.8 & 215 & 340106 \\
\hline 8 & 2049_7 & $204 / 9$ & 1.68 & 33.7 & 1.03 & 70.1 & 6.9 & 211 & 329648 \\
\hline 9 & 2049_8 & $204 / 9$ & 1.67 & 33.9 & 1.07 & 73.7 & 7.3 & 205 & 313706 \\
\hline 10 & 2049_9 & $204 / 9$ & 1.66 & 34.1 & 1.11 & 74.2 & 8.0 & 208 & 277099 \\
\hline
\end{tabular}

Fig. 9. Data regarding exploitation lots in Excel

Rys. 9. Dane dotyczące parcel eksploatacyjnych w programie Excel 


\begin{tabular}{|c|c|c|c|c|c|c|c|c|c|c|}
\hline Year & Month & Lots & $\begin{array}{c}\text { Thickness } \\
{[\mathrm{m}]}\end{array}$ & $\begin{array}{c}\text { Specific } \\
\text { gravity } \\
{\left[\mathrm{G} / \mathrm{cm}^{3}\right]}\end{array}$ & $\begin{array}{c}\text { Volatiles } \\
{[\%]}\end{array}$ & $\begin{array}{c}\text { Total } \\
\text { sulfur } \\
{[\%]}\end{array}$ & $\begin{array}{l}\text { Roga } \\
\text { Index }\end{array}$ & $\mathrm{FSI}$ & Dilatation & $\begin{array}{l}\text { Ash } \\
\text { [\%] }\end{array}$ \\
\hline & 8 & 2049_1 & 1.7 & 1.49 & 33.2 & 1.01 & 74.8 & 7.6 & 114 & 8.2 \\
\hline & 9 & 2049_2, 2082_4 & 2.2 & 1.47 & 19.4 & 0.53 & 71.7 & 7.0 & 198 & 5.6 \\
\hline \multirow[t]{5}{*}{2022} & 10 & 2049_2 & 1.8 & 1.53 & 33.4 & 1.01 & 74.0 & 7.5 & 143 & 4.1 \\
\hline & 11 & 2049_2,2049_6 & 2.3 & 1.60 & 33.4 & 1.00 & 71.8 & 7.2 & 178 & 4.8 \\
\hline & 12 & 2049_2,2049_6 & 2.3 & 1.60 & 33.4 & 1.00 & 71.8 & 7.2 & 178 & 4.8 \\
\hline & 1 & 2049_2,2049_6 & 2.3 & 1.60 & 33.4 & 1.00 & 71.8 & 7.2 & 178 & 4.8 \\
\hline & 2 & 2049_2,2049_6 & 2.3 & 1.60 & 33.4 & 1.00 & 71.8 & 7.2 & 178 & 4.8 \\
\hline \multirow[t]{2}{*}{2023} & 3 & 2049_2,2049_6 & 2.3 & 1.60 & 33.4 & 1.00 & 71.8 & 7.2 & 178 & 4.8 \\
\hline & 4 & 2049_2,2049_6 & 2.3 & 1.60 & 33.4 & 1.00 & 71.8 & 7.2 & 178 & 4.8 \\
\hline
\end{tabular}

Fig. 10. Statement of coal quality on particular dates

Rys. 10. Zestawienie jakości węgla w poszczególnych datach

- draw a closed area,

- indicate 2 lines - the program connects them so that a closed area is created,

- indicate the lines inside which we want to create a lot - we indicate the lines that limit the lot and then the point inside the lot (Fig. 11).

- indicate the existing contour of the lot (closed polyline),

- then we indicate the centroid existing in the figure and specify the block insertion point. We complete the data we have - we enter the lot number, thickness, dip (the value of the dip is given in degrees), type of coal, density, calorific value, ash, sulphation. We choose the recognition categories of the deposit from expanding files. The box surface is completed by the program automatically.

After inserting the centroid, the program will automatically color the indicated area.

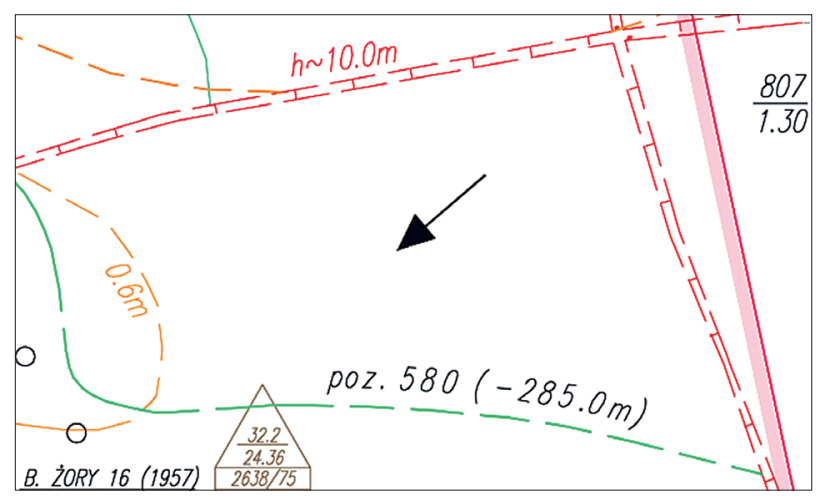

Fig. 11. Creating a geological lot

Rys. 11. Tworzenie parceli geologicznej
The program also allows you to edit lots. We point to centroid and introduce changes. After accepting, the program updates both the centroid and the coloring of the lot. An important functionality of the system is also the control of the correctness of creating the lots (whether the centroid is related to the border of the lot). Errors can be viewed using the command ZNN. In order to check the topology, it is recommended to do the following:

- We perform control of the lots (we check if the centroids are properly linked to lots). The errors found by the program should be corrected.

- We hide unneeded layers in the figure and move the blocks with references so that the insertion point of the block and the reference point overlap.

- We create a topology of closed polygons - and we indicate in turn the centroid and line as the pattern. We start the program until there are no

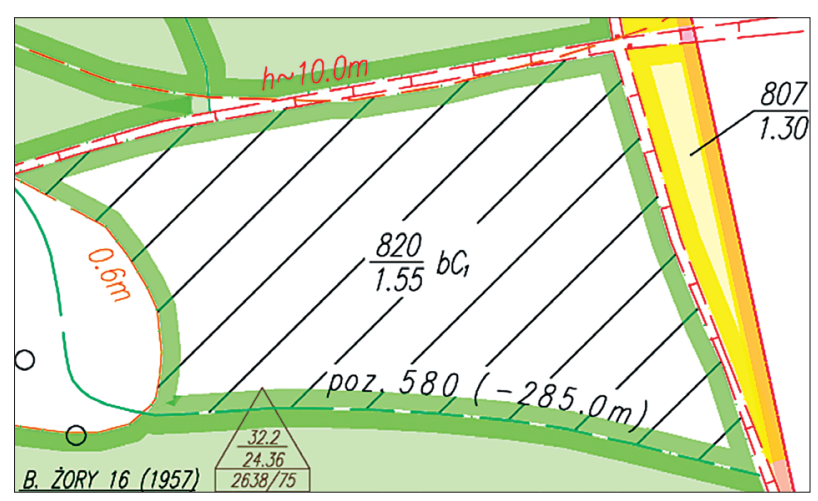




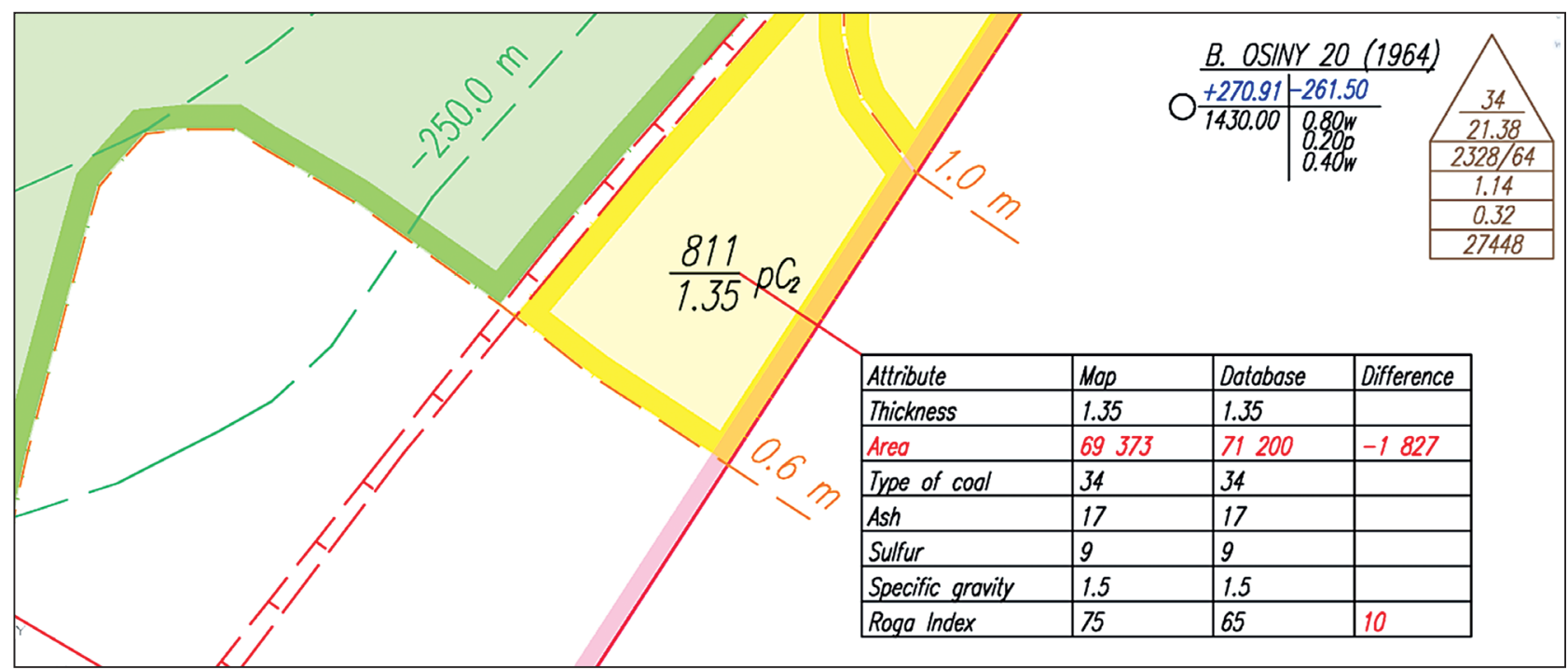

Fig. 12. Comparison of graphic edition of geological lots with data in the Oracle database

Rys. 12. Porównanie edycji graficznej parcel geologicznych $z$ danymi w bazie Oracle

errors in the figure. After launching the TOPO command, the topo dialog box appears, including: the value of admissible deviation - if the value $>0$ is entered, the program will firstly correct shortcomings and short sections within the specified tolerance; for a value equal to 0 the program will not clean the figure; minimum angle - checks whether the angle between the neighboring sides is greater than the given value; the shortest side checks if all the lines are longer than the given value; round the coordinates - rounds the coordinates to the given number of decimal places.

Controls may include: all centroids, unused centroids, additional line data, backyards, which are closed areas surrounded by lots, which are not lots themselves. First, the program checks the occurrence of short sections and shortcomings of the line and then checks whether each lot is described. The above actions can be performed in the mode of interaction with the user. After making corrections, we reconstruct the topology.

Among other tasks, important from the point of view of numerical modeling of deposit quality, the following should be mentioned:

- generating a report on the lots visible on the map,

- finding, according to specific criteria, and selecting the lots with specific values. The found objects can be looked through/reviewed in the figure.
- comparing the /lot with the database by selecting objects in the graphical editing mode (Fig. 12). Data can be downloaded from: Oracle database, Oracle history, xml file, csv file. For every checked /lot, the program includes a table in which the data describing this lot on the map and in the database are compiled. The difference is shown in the column error.

- determining the display order of objects,

- comparing the lots located on the map with the database,

- exporting the descriptive attributes of lots to an Excel file,

- saving lots to the Oracle database,

- settling the resources to Excel,

- updating the lots.

\section{SMOOTHING AND EXTRAPOLATING THE SURFACE OF TRIANGLES}

Smoothing the surface consists in calculating and inserting new points to the surface, e.g. in the centroids of existing triangles. In this way, the surface consists of more points and the generated contour lines have a more rounded shape. In AutoCAD Civil 3D, as in other popular geological programs, there are many methods and options for smoothing the TIN surface (Błaszczak-Bąk et al., 2018). Their proper selection is not easy. When 
modeling the geometry and quality parameters of hard coal, we have very little data, so it is difficult to use advanced geostatistical methods. In addition, there are numerous discontinuity lines in the coal seam: faults, seam adhesion lines, etc., which can cause a step change of the value of a given parameter. Despite these difficulties, the authors managed to choose several methods that worked well in practice. Some of the most important issues are shown below.

\subsection{The choice of method}

The most commonly used methods are: Natural Neighbor Interpolation (NNI) and Ordinary Kriging (Zawadzki, 2011). In the first method, the centroid of each triangle can be calculated as the intersection of its medians, so it is not possible to extrapolate the points beyond the existing boundaries of the surface. This method does not change the shape of the surface, but only in- creases the number of points. Kriging is a geostatistical method of smoothing, in which the model of the terrain can be imagined in the form of a sum of functions, e.g. polynomial and non-linear residue. Unlike NNI, we can extrapolate points beyond the boundary of the surface.

To sum up, if one only wants to increase the number of points, NNI should be chosen, and in order to extrapolate the area or find a certain trend (see point 5.3), you should select Kriging.

\subsection{Kriging Semivariogram Model}

Instead of a polynomial another function can be used: Spherical, Exponential, etc. In practice, Linear or Gaussian ones are used. The difference between them is shown in Fig. 13 and Fig. 14. Based on the same data, the thickness of the seam $2 \mathrm{~m}, 3 \mathrm{~m}$ and $4 \mathrm{~m}$, two different models are obtained. In the Linear model, along with moving away from the data, the variability of the

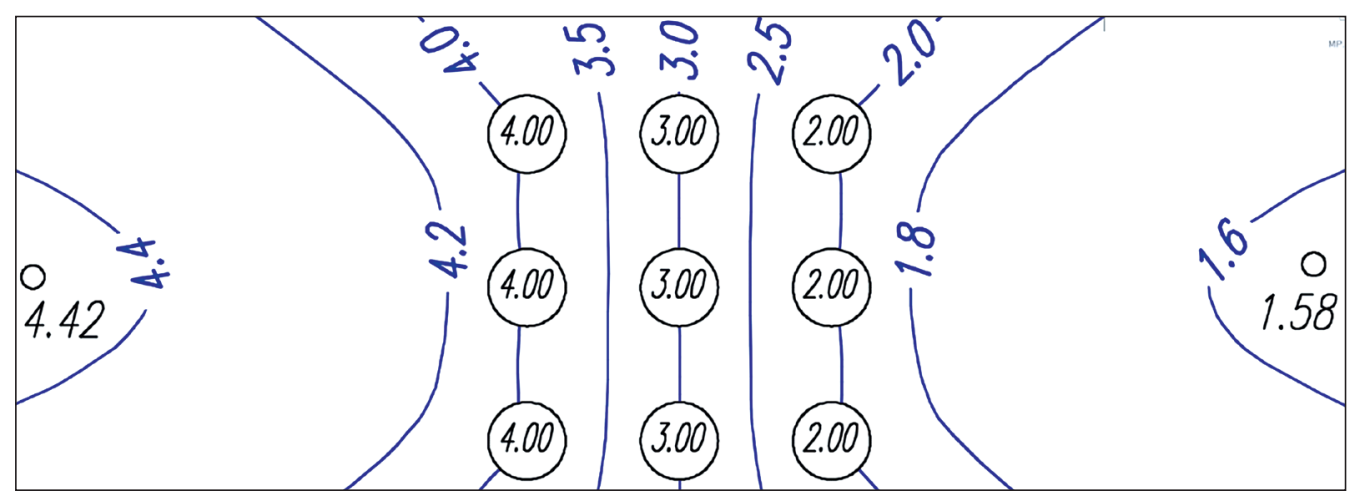

Fig. 13. Extrapolation using a Kriging Linear Semivariogram Model

Rys. 13. Ekstrapolacja przy użyciu metody Kriging, liniowy model semiwariancji

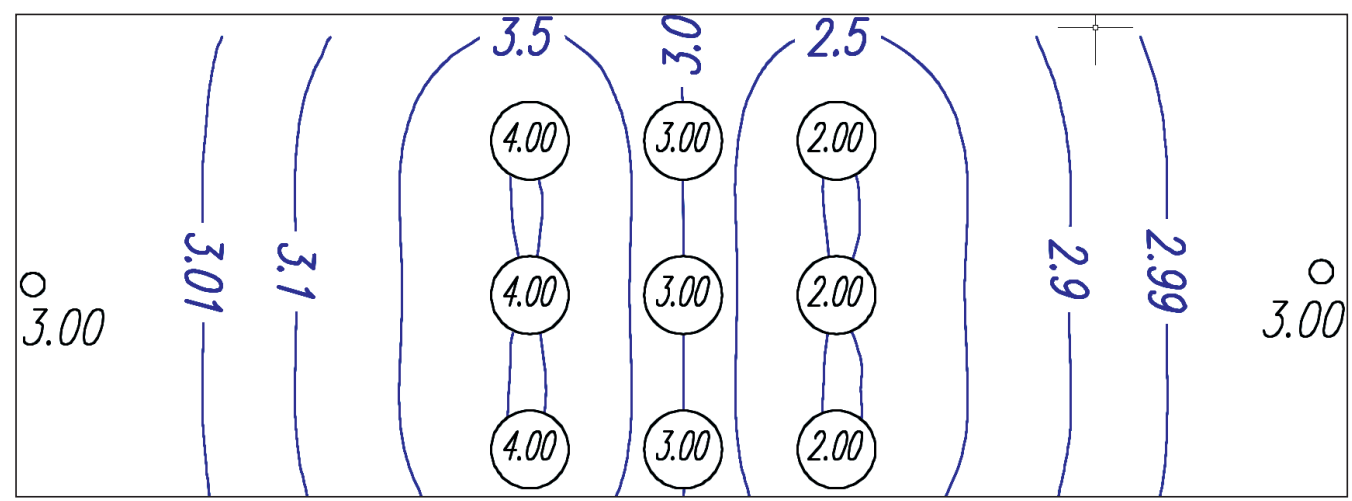

Fig. 14. Extrapolation using a Gaussian Semivariogram Model

Ryc. 14. Ekstrapolacja przy użyciu metody Kriging, gaussowski model semiwariancji 
function decreases on the right to 1.5 - below this value it does not change anymore, on the left it grows to 4.5. In the Gaussian model, the function outside the subject area /tends to the mean, in this case 3.0.

It is better to use Linear Kriging (Fig. 13) in modeling the seam footwall and when the distance from the measurement points is slight. Gaussian Kriging (Fig. 14) is used more often when the distances between measuring points are so large that it is safer to assume the average of the entire seam in a given place than to try to predict what value is correct.

As already mentioned, due to the small amount of measurement data and the occurrence of numerous discontinuity lines, more advanced methods, such as, e.g. Block Kriging, are not applicable in hard coal mining.

\subsection{Nugget Effect}

Nugget Effect determines the discontinuity at the beginning of the semivariogram model. The higher its value, the smoother the model is; the smaller its value, the more accurate it is - the model adheres more to the measurement points. If you want to find the trend of the function and get the maximum smoothing of the surface, in addition to setting a large value of the Nugget Effect, the original measurement points should be removed from the model and only the interpolated ones should be left. This is done because the original points will spoil the smoothing effect and around them closed contour lines will appear, which will look unsightly on the printout. Some geological programs, e.g. Surfer, operate only on interpolated points. However, care should be taken when removing original points. If the wrong parameters of the Kriging function are chosen, we will see many unnecessary contour lines at the original points and immediately realize that we have made a mistake somewhere.

In mining practice, the minimum (zero) values of the Nugget Effect are used and the original measurement points remain. This means that we focus on the accuracy of calculations at the expense of the aesthetics of isolines.

\subsection{Model of triangles vs model of squares}

We usually use two ways of compacting points: creating a grid of triangles or a grid of squares. The triangle grid has many advantages:
- The TIN grid is based on original points, which increases the accuracy of the analysis and naturally facilitates the introduction of discontinuity lines. We can thicken it by introducing points in the centroids of triangles, which means that after compaction we still have a grid of triangles.

- When creating a grid of triangles in an area where is a large variation of a given parameter, we introduce a lot of points, and in the remaining areas few points, while in the case of a grid of squares, the entire area must be covered with a uniform, very dense grid. If a grid of triangles is used, sufficient coverage of the mining area of an average mine is provided by several hundred points. When using a grid of squares to provide similar, but still with less accuracy, it is necessary to use at least tens of millions of these points. This affects the length of all calculations.

- If we have 4 points, it is possible to make triangles in two ways: vertically or horizontally. The way of running triangles has a significant impact on the course of isolines and any analysis of the deposit model. Introducing a change in the structure of the triangles is very simple: just point the wrong edge and the program will rebuild the entire surface. The grid of squares is much harder to edit manually.

- As presented in section 5.3, leaving the original points in the model makes it difficult to accidentally enter an incorrect interpolation algorithm.

\subsection{The impact of isoline rounding on the model accuracy}

Mostly, we visualize the spatial model of the deposit by placing $2 \mathrm{D}$ objects on the map: graphs, cross-sections and, above all, isolines. If we design new exploitation walls, we try not to exceed the minimum isoline of thickness, for example $1.4 \mathrm{~m}$. Therefore, this isoline should be drawn as accurately as possible. But on the other hand, the isolines are to be nicely smoothed, quite simply without any twists or loops. This effect can be achieved in two ways: smoothing the isoline (creating a spline) and smoothing the surface. The latter method, which combines the accuracy of plotting the isoline with the aesthetics of the printout, is definitely worth recommending. 


\section{SUMMARY}

The system presented in the article, applied in Polish hard coal mines to develop a numerical model of the deposit, allows for streamlining the implementation of tasks in the field of underground mining plant operation. The authors presented only a narrow scope of the system's functionality, with particular attention to data which allow for modeling the quality of the deposit. Numerical modeling of the deposit quality enables more efficient production management, thanks to the quick acquisition of comprehensive data regarding both the size as well as quality parameters of resources. The data allow for proper planning of production as well as current assessment of the quality of the extracted raw material, by using appropriate methods, also for forecasting its quality, which is of great economic importance. This solution is most effectively used in Jastrzębska Coal Company Inc., the largest producer of coking coal in the European Union and Polish Mining Group Inc. The advantage of the system is that its functionalities are systematically extended to adapt to the current needs of mining entrepreneurs.

The article also presents a number of authorial solutions in the field of optimal smoothing and extrapolation of the surface of the deposit quality.

Finally, it can be mentioned that there is a free MPNMT module available on the website (www.geolisp.pl 2019), which contains many of the features described in the article.

\section{BIBLIOGRAPHY}

Biegun D., Krawczyk A. (2016). Methods of use two-dimensional CAD application environment of mining digital maps to generate three-dimensional modeling of the geological surface layer. Geoinformatica Polonica, vol. 15, pp. 47-55.

Błaszczak-Bąk W., Poniewiera M., Sobieraj-Żłobińska A., Kowalik M. (2018). Reduction of measurement data before Dig- ital Terrain Model generation vs. DTM generalization. Survey Review. DOI 10.1080/00396265.2018.1474685.

Chen A., Qin D., Zhang X., Jia G., Tan S., Fan Z. (2004). The application of deposit $3 D$ model based on micromine". Geology and Prospecting, 30(3), pp. 77-80.

Jelonek I.; Poniewiera M., Gąsior B. (2015). The qualitative model of the deposit on the example of the Kompania Weglowa S.A. Part I: Stages in the development of the digital model the deposit. Schriftenreihe der Deutschen Gesellschaft für Geowissenschaften, vol. 87, p. 91.

Jelonek I., Poniewiera M., Jelonek Z. (2017). Modeling of deposits on the basis of petrographic properties of solid minerals on the example of JSW S.A. Górnictwo Odkrywkowe, vol. 2, pp. 14-20.

Klemens J., Poniewiera M. (2010). The use of the latest information technology to support the geodetic and geological processes in Kompania Weglowa SA. Przegląd Górniczy, vol. 10, pp. 3-10.

Maciaszek J., Wąsacz W., Szewczyk J. (2015). Mapa górnicza jako dokument elektroniczny. Przegląd Górniczy, vol. 71, no. 3, pp. 64-71.

Poniewiera M., Jelonek I., Gąsior B. (2015). Numerical model of bituminous coal deposit constructed on the base of coal quality parameters - Part I. Journal of Civil Engineering, Environment and Architecture, vol. 62, pp. 379-394.

Poniewiera M., Jelonek I., Błaszczak-Bąk W. (2019). The optimal position of pumping station based on the digital terrain model. Journal of Water and Land Development, vol. 40, pp. 103-111. DOI 10.2478/jwld-2019-0011.

Regulation of the Minister for Environment of October 28, 2015 on the measuring and geology documentation. Dziennik Ustaw 2015, poz. 1941, Poland. (Journal of Laws 2015, item 1941, Poland).

Sokoła-Szewioła V., Poniewiera M. (2017). Selected possibilities of the GIS data import in programs AutoCAD Civil 3D and Geolisp. Geoinformatica Polonica, vol. 16, pp. 69-76. DOI 10.4467/21995923GP.17.005.7192.

Sokoła-Szewioła V., Poniewiera M. (2019). Application of a digital model of deposit in Polish hard coal mines on the example of Polish Mining Group Ltd." Proceedings in Earth and Geosciences, vol. 3, pp. 344-356. DOI 10.1201/9780429320774.

Zawadzki J. (2011). „Metody geostatystyczne dla kierunków przyrodniczych i technicznych". Oficyna Wydawnicza Politechniki Warszawskiej. Warszawa.

http://www.geolisp.pl/pliki/mp-dtm.zip (accessed on 28 June 2019). 